\title{
Plant-based pharmacological alternatives in the seizure treatment: A patent review
}

\section{Alternativas farmacológicas baseadas em plantas para o tratamento de convulsões: Uma revisão de} patentes

Alternativas farmacológicas a base de hierbas para el tratamiento de las convulsiones: Revisión de patente

\author{
Lícia Tairiny Santos Pina \\ ORCID: https://orcid.org/0000-0002-2926-2034 \\ Federal University of Sergipe, Brazil \\ E-mail: licia tairinypina2008@ hotmail.com \\ Adriana Gibara Guimarães \\ ORCID: https://orcid.org/0000-0003-1643-5642 \\ Federal University of Sergipe, Brazil \\ E-mail: adrianagibara@hotmail.com \\ Laeza Alves Sampaio \\ ORCID: https://orcid.org/0000-0002-2798-3866 \\ Federal University of Sergipe, Brazil \\ E-mail: laeza.sampaio@hotmail.com \\ Juliana Oliveira Guimarães \\ ORCID: https://orcid.org/0000-0002-3361-6587 \\ Federal University of Sergipe, Brazil \\ E-mail: jullyoliveiraguimaraes@gmail.com \\ Thallita Kelly Rabelo \\ ORCID: https://orcid.org/0000-0002-9047-8133 \\ Federal University of Sergipe, Brazil \\ E-mail: talitabioq@gmail.com \\ Flávia Medeiros Savi \\ ORCID: https://orcid.org/0000-0003-0067-8308 \\ Queensland University of Technology: Brisbane, Australia \\ E-mail: flavia_savi@hotmail.com \\ Mairim Russo Serafini \\ ORCID: https://orcid.org/0000-0003-4223-3470 \\ Federal University of Sergipe, Brazil \\ E-mail: maiserafini@hotmail.com
}

\begin{abstract}
Epilepsy, a neurologic condition associated with recurring seizures, affects around 70 million people worldwide and it is responsible for health costs. The current drug therapies used for treating epilepsy have low efficacy and many adverse side effects. In addition, drug resistance can also be found. The association of these factors considerably compromises the patient's pharmacotherapy care. Therefore, natural plant-derived products are promising therapeutic alternatives in the search for new curative options to treat epileptic seizures. Thus, the search was carried out at the patents database in the world, Espacenet, in January 2021 and compiled plant species (extracts, essential oils and isolated plant compounds) with a potential effect on the seizure, published between 2015 and 2020. In recent years, researchers and pharmaceutical companies have developed several methods for obtaining extracts, essential oils and purification of natural compounds, which have proven to be effective for the treatment of epileptic seizures in preclinical animal models. These findings hold potential promising for the treatment of epilepsy, especially for the management of drug-resistant, however, these reports are in their early stages and further studies need to be done for these compounds to be marketed.
\end{abstract}

Keywords: Medicinal plants; Seizure; Epilepsy; Anticonvulsant.

\section{Resumo}

A epilepsia, uma condição neurológica associada a crises recorrentes, afeta cerca de 70 milhões de pessoas em todo o mundo e é responsável por custos de saúde. As terapias medicamentosas atuais utilizadas para o tratamento da epilepsia têm baixa eficácia e muitos efeitos colaterais adversos. Além disso, a resistência aos medicamentos também pode ser encontrada. A associação desses fatores compromete consideravelmente os cuidados farmacoterapêuticos do paciente. Portanto, produtos naturais derivados de plantas são alternativas terapêuticas promissoras na busca de novas 
opções terapêuticas para o tratamento de crises epilépticas. Assim, a busca foi realizada na maior base de patentes do mundo, Espacenet, em janeiro de 2021 e compilou espécies vegetais (extratos, óleos essenciais e compostos vegetais isolados) com potencial efeito na convulsão, publicadas entre 2015 e 2020. Nos últimos anos, pesquisadores e empresas farmacêuticas desenvolveram diversos métodos para obtenção de extratos, óleos essenciais e purificação de compostos naturais, que se mostraram eficazes para o tratamento de crises epilépticas em modelos animais préclínicos. Esses achados apresentam potencial promissor para o tratamento da epilepsia, principalmente para o manejo de fármacos resistentes, porém, esses relatos estão em seus estágios iniciais e mais estudos precisam ser feitos para que esses compostos sejam comercializados.

Palavras-chave: Plantas medicinais; Convulsão; Epilepsia; Anticonvulsivante.

\section{Resumen}

La epilepsia, una afección neurológica asociada con convulsiones recurrentes, afecta a alrededor de 70 millones de personas en todo el mundo y es responsable de los costos de salud. Las terapias farmacológicas actuales utilizadas para tratar la epilepsia tienen una eficacia baja y muchos efectos secundarios adversos. Además, también se puede encontrar resistencia a los medicamentos. La asociación de estos factores compromete considerablemente la atención farmacoterapéutica del paciente. Por lo tanto, los productos naturales derivados de plantas son alternativas terapéuticas prometedoras en la búsqueda de nuevas opciones terapéutica para tratar las crisis epilépticas. Así, la búsqueda se realizó en la base de datos de patentes más grande del mundo, Espacenet, en enero de 2021 y recopiló especies vegetales (extractos, aceites esenciales y compuestos vegetales aislados) con potencial efecto en las convulsiones, publicadas entre 2015 y 2020. En los últimos años, investigadores y compañías farmacéuticas han desarrollado varios métodos para la obtención de extractos, aceites esenciales y purificación de compuestos naturales, que han demostrado ser efectivos para el tratamiento de ataques epilépticos en modelos animales preclínicos. Estos hallazgos tienen un potencial prometedor para el tratamiento de la epilepsia, especialmente para el manejo de la resistencia a los medicamentos; sin embargo, estos informes se encuentran en sus primeras etapas y es necesario realizar más estudios para comercializar estos compuestos.

Palabras clave: Plantas medicinales; Convulsiones; Epilepsia; Anticonvulsivo.

\section{Introduction}

Epilepsy is a chronic neurological condition among the most prevalent central nervous system disorders, that affects approximately 70 million people worldwide (Beghi, 2020; Thijs et al., 2019; Thurman et al., 2011). It is characterized by the recurrence of unprovoked seizures caused by abnormal and excessive activity of brain neurons in an unpredictable manner (Fisher et al., 2005, 2017; Stafstrom \& Carmant, 2015). Epilepsy has no cure, but it can be treated using surgical procedures or medications (Byun et al., 2020; Catchpool et al., 2019). The first-line treatment involves the use of antiepileptic medications, such as carbamazepine and gabapentin, which must be customized and based on medical and psychiatric considerations (Johnson, 2019). Inappropriate treatment of epilepsy leads to several problems for patients, including low quality of life, higher risk of sudden death, and greater chances of developing physical, psychological, and social comorbidity conditions (Siarava et al., 2019; Tomson et al., 2008). When treated correctly, patients suffering from seizures manage to lead a normal life (Guerreiro, 2016).

Over the past decades, most of the development of anti-epileptic drugs has been based on the use of pre-clinical epilepsy models induced by pentylenetetrazole (PTZ) (Shimada \& Yamagata, 2018), maximum electroshock (MES) (Socała et al., 2019) and on the use of pilocarpine (Kim \& Cho, 2018). Although the number of antiepileptic medications available on the market has grown exponentially, the percentage of people with intractable seizures remains high (Z. Chen et al., 2018; Johnson, 2019) and issues associated with conventional treatments, specially drug resistance, are still frequent (more than $30 \%$ of individuals) (Chen et al., 2018; Mesraoua et al., 2019; Ryvlin, 2005). Although, several criteria have been adopted to classify drug resistance, a precise criterion has not been agreed on. A hierarchical level framework to characterize therapeutic interventions to trials has been suggested by Kwan et al (2010), where failure to at least two antiepileptic drug interventions, used alone or in combination, validates drug resistance (Kwan et al., 2010).

Lately, considerable attention has been given to the use of vegetal species as a new therapeutic approach for the treatment and control of recurrent seizures (Bulaj et al., 2016; Pina et al., 2020), including the use of plant extracts (Quintans 
Júnior et al., 2008), essential oils (da Fonsêca et al., 2019) and isolated compounds, such as cannabidiol (Samanta, 2019). Since ancient times, and yet aiming at establishing a balance between the physiological systems and providing healing, traditional Chinese medicine has used natural products to improve human health and well-being (Ma et al., 2016). Indeed, the application of these vegetal species has been remarkedly investigated and largely used to combat drug-resistant bacteria and viruses, infectious diseases, cancer, and as central nervous system disorders, including alzheimer, parkinson e recurrent seizures (Huyan et al., 2016; Makaremi et al., 2021; Marshall, 2020; Veeresham, 2012; Vilasboas-Campos et al., 2020; Vyas et al., 2019; Y. Wang et al., 2017). In contrast to conventional therapies, these products have lesser side effects and higher tolerability, making these products a promising therapeutic alternative in the search for new antiepileptic drug options (Deivasigamani et al., 2021; Popovych et al., 2020; Verma et al., 2021).

As these new natural therapeutic alternatives become more readily available (Pina et al., 2020), so does the need for further scientific discoveries and drug development as existing conventional drugs have only symptomatic effects. Pre-clinical animal model studies are essential for establishing efficacy and adjusting the safety profile of these novel substances prior their translation into clinical settings (Löscher, 2011, 2017). Thus, the objective of this review is to conduct a survey on the recent patent fillings of new therapeutic plant-based alternatives used for treating epilepsy and/or seizures, published between 2015 and 2020.

\section{Methodology}

The patent search for this review was carried out using one of the largest patents data base in the world (ESPACENET) in January 2021. The criteria search included patents published between 2015 and 2020 related to the use of anticonvulsant natural/pant-based products with clinically relevant activity in humans; and the International Patent Classification (IPC) A61P25/08 (antiepileptics, anticonvulsants) and A61K36 (medicinal preparations containing algae, lichens, fungi or plants or their derivatives) categories.

The following inclusion criteria were applied for the selection of patents: vegetal species (extracts, essential oil and compounds isolated from plants) with in vivo anticonvulsant effect studies applied to patients suffering from epilepsy and/or seizures. Patents in which mixtures of plants or extracts, combinations with other drugs and duplicates were excluded.

\section{Results}

Initially, 607 patents were found comprising the use of natural products and anticonvulsants. However, not all patents provided scientific evidence of an anticonvulsant effect. Thus, 16 patents were selected by read in full (Figure 1). The selection showed that 2018 was responsible for the largest number of patent inventions filings, accounting for $31.25 \%(\mathrm{n}=5)$. Despite the year 2019 there was a decrease in the number of patent filings, 2020 appears with an increase, being the second year with the highest numbers of filings growth $(n=4 ; 25 \%)$, presenting a growth tendency as can be seen in Figure 2 . 
Figure 1. Flowchart of included patents.

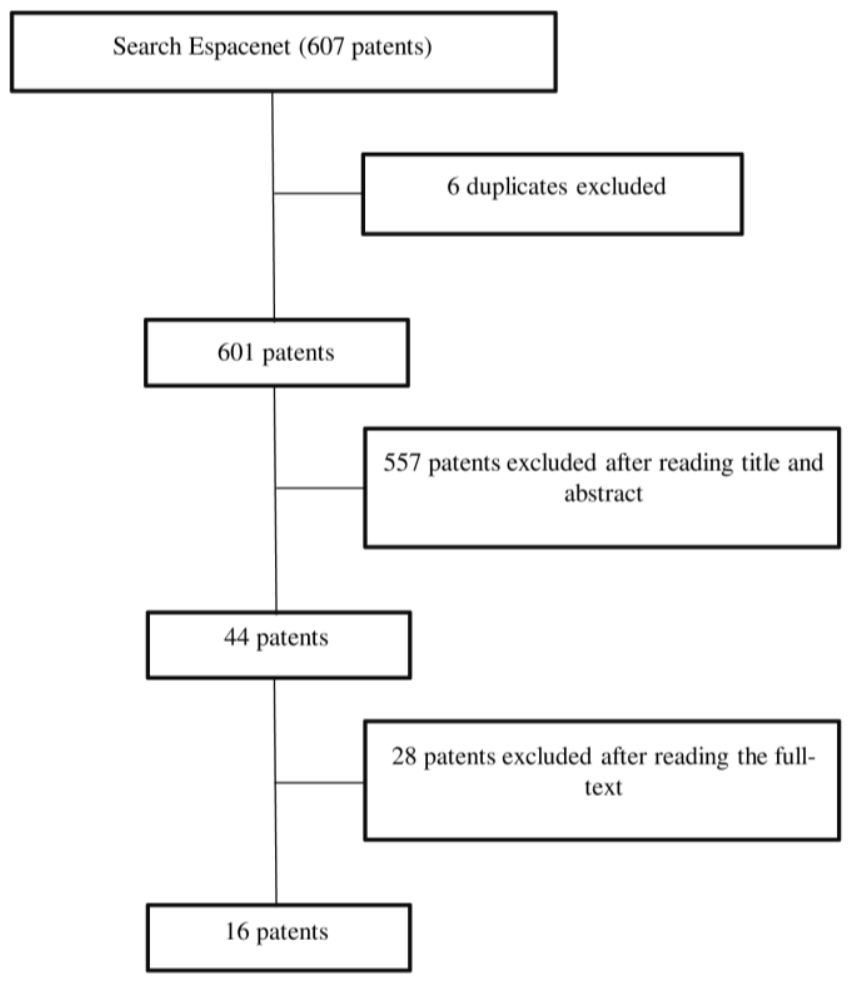

Source: Prepared by the authors.

Figure 2. Distribution of number of patents per year.

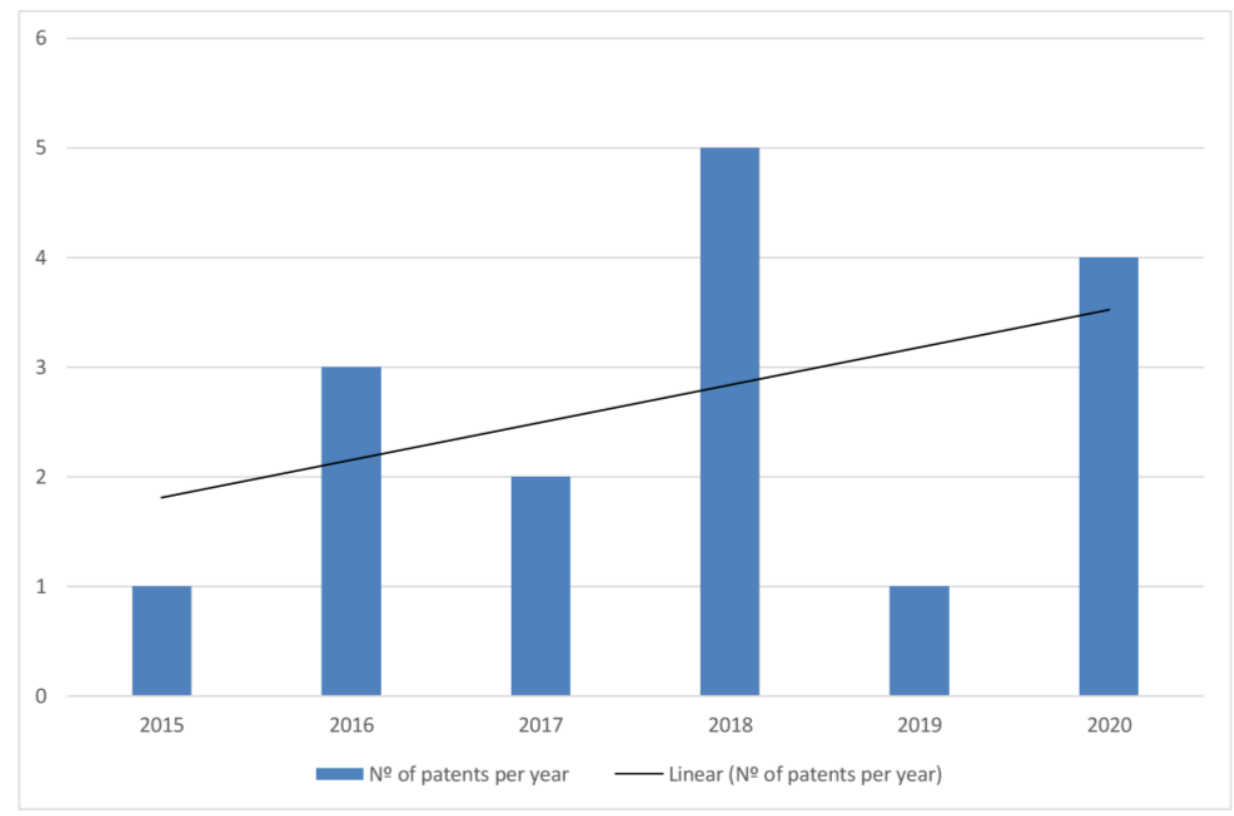

Source: Prepared by the authors.

The middle-income country of China accounted for the majority of patent inventions related to innovative compounds based on vegetal species with anticonvulsant activity, accounting for $56.25 \%(\mathrm{n}=9)$ of the total published applications. The United Kingdom filed 31.25\% $(n=5)$ of total patents found, followed by Spain and Russia with 6.25\% ( $n=1$ each) (Figure 3). These findings could be related to the fact that approximately $80 \%$ of patients suffering from epilepsy are located in developing countries, including China (66\%) and India (95\%) (Ding et al., 2019), and hence resulting in an increased interest 
for finding effective new compounds. Determinants of pharmaceutical R\&D research investments, which are based on proof of the effectiveness of traditional medicine, socioeconomic costs resulting from hospitalizations and consequences on the patient's quality of life, also would account to these results (Chatterjee et al., 2020; Ding et al., 2019; Yu et al., 2019).

Figure 3. Distribution of patent deposits by countries. CN: China; GB: United Kingdom; ES: Spain; RU: Russian Federation.

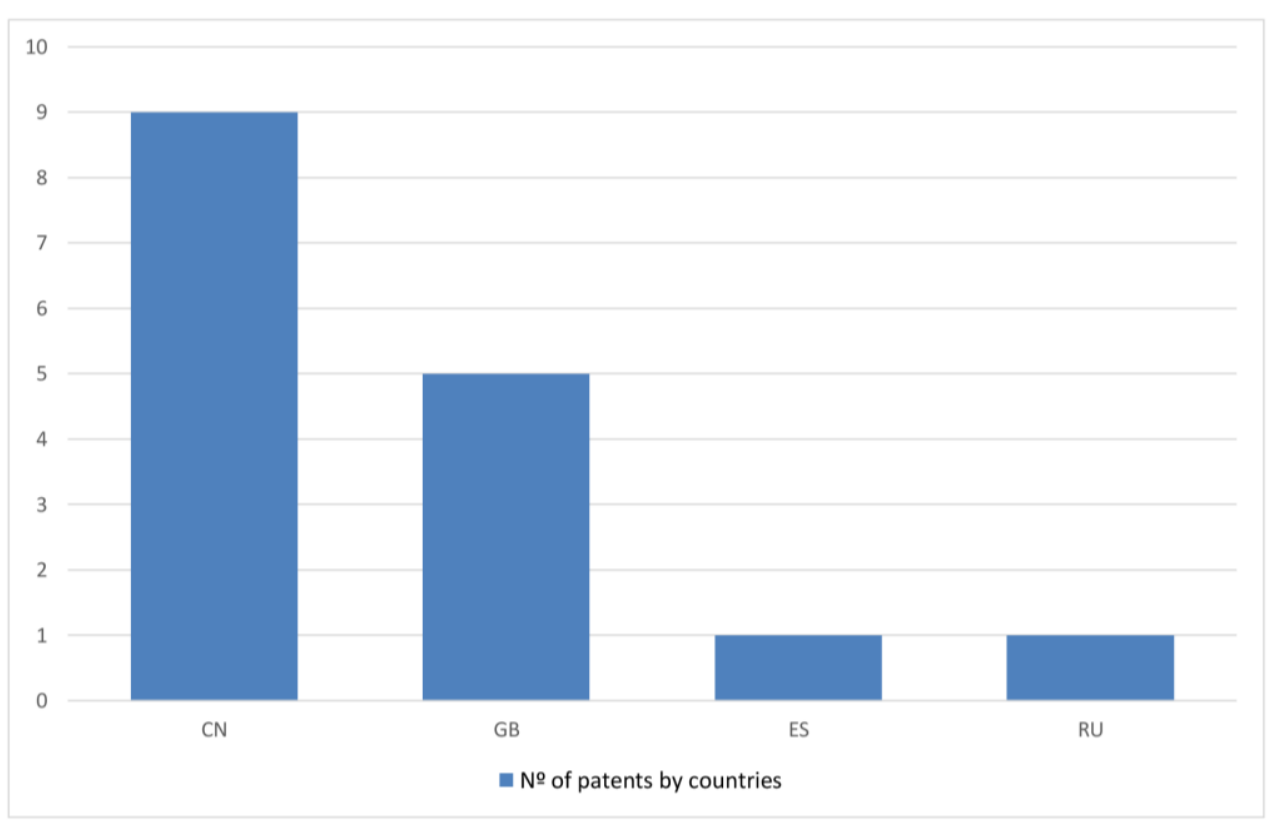

Source: Prepared by the authors.

The university and business sectors were responsible for the majority of published applications with $37.5 \%(n=6)$ and $31.25 \%(n=5)$, respectively. These sectors mainly sought to investigate the effectiveness of using traditional medicine in humans and to propose new alternative products to standard drug-resistant epilepsy treatments (Auditeau et al., 2019; Mathon et al., 2020). A small number of patents were filed by individuals $(25 \%, \mathrm{n}=4)$ and a minor share filed by university and companies' partnership $(6.25 \%, \mathrm{n}=1)$.

All published patents in this study reasoned their invention findings and respective anticonvulsant effects based on pre-clinical studies. The most used models to screen for antiepileptic drugs were the convulsion induced by administration of PTZ $(52.63 \%, \mathrm{n}=10)$, MES $(15.79 \%, \mathrm{n}=3)$ and an association of pilocarpine and lithium chloride $(15.79 \%, \mathrm{n}=3)$, which mimic generalized and focal seizures. The remaining models represent $15.79 \%(\mathrm{n}=1$, each) and include febrile seizure, administration of kainate acid and strychnine.

This review reports 10 extracts, 1 essential oil and 8 isolated compounds from plants tested in seizure models (Table 1). Luo et al. (2015) obtained an extract from the dry root powder of the Salvia mitliorrhiza plant using ultrasound and acetone as the extraction solvent. Additionally, the authors have also identified the tanshinone IIA (6,6-Trimethyl-6,7,8,9tetrahydrofenantro [1,2-b] furan-10, 11-dione) using high-pressure liquid chromatography (HPLC). Tanshinone IIA is a multitarget drug known for its wide-ranging remedial effects, including protective properties in neurodegenerative diseases $(\mathrm{Xu} \&$ Liu, 2013). Both the extract and the isolated compound were tested at doses of $0.1,1.0$ and $10 \mathrm{mg} / \mathrm{kg}$, intravenous (i.v.), and demonstrated effectiveness against convulsions induced by PTZ infusion and corneal stimulation in mice. Due to their neuroprotective effects, these compounds can be used as an alternative antiepileptic drug treatment (Luo et al., 2015). 
Research, Society and Development, v. 11, n.2, e40411225940, 2022

(CC BY 4.0) | ISSN 2525-3409 | DOI: http://dx.doi.org/10.33448/rsd-v11i2.25940

Table 1. Plant-based pharmacological alternatives anticonvulsant patented between 2015-2020.

\begin{tabular}{|c|c|c|c|c|c|c|c|c|c|}
\hline $\begin{array}{l}\text { Publication } \\
\quad \text { Year }\end{array}$ & $\begin{array}{l}\text { Inventor/ } \\
\text { Company } \\
\text { (Country) }\end{array}$ & IPC & $\begin{array}{c}\text { Plant/ } \\
\text { Compound (s) }\end{array}$ & Obtainment & $\begin{array}{l}\text { Experimental } \\
\text { model/animal }\end{array}$ & $\begin{array}{l}\text { Evaluation } \\
\text { parameters }\end{array}$ & $\begin{array}{l}\text { Dose } \\
\text { (via) }\end{array}$ & Outcome & Reference \\
\hline 2015 & $\begin{array}{c}\text { Luo Guon et al./ } \\
\text { University Leuven } \\
\text { Kath (BE) } \\
\text { University Tsinghua } \\
\text { (CN) }\end{array}$ & $\begin{array}{l}\mathrm{A} 61 \mathrm{~K} 36 / 537 \\
\mathrm{~A} 61 \mathrm{P} 25 / 08\end{array}$ & $\begin{array}{l}\text { Salvia miltiorrhiza and } \\
\text { Tanshinone IIA }\end{array}$ & $\begin{array}{l}\text { Acetone extract and } \\
\text { isolation }\end{array}$ & $\begin{array}{l}\text { PTZ (i.v. infusion } 7.5 \\
\mathrm{mg} / \mathrm{mL} \text { ) and } 6-\mathrm{Hz} \\
\text { corneal stimulation in } \\
\text { mice }\end{array}$ & Number of seizure & $\begin{array}{l}10,1 \text { and } 0.1 \\
\mathrm{mg} / \mathrm{kg} \text {, i.v. }\end{array}$ & Reduction of seizure & $\begin{array}{l}\text { WO201500409 } \\
3\end{array}$ \\
\hline 2016 & Hu Kai et al. (CN) & $\begin{array}{l}\text { A61K36/46 } \\
\text { A61P25/08 }\end{array}$ & Aucubin & $\begin{array}{l}\text { Isolated from } \\
\text { Eucommia ulmoides } \\
\text { ethanol extract }\end{array}$ & $\begin{array}{l}\text { Pilocarpine }(20 \mathrm{mg} / \mathrm{kg} \text {, } \\
\text { i.p.) and lithium chloride } \\
(125 \mathrm{mg} / \mathrm{kg} \text {. i.p. }) \text { in rats }\end{array}$ & $\begin{array}{l}\text { Racine scale, EEG and } \\
\text { immunohistochemistry }\end{array}$ & $\begin{array}{l}5 \text { and } 10 \mathrm{mg} / \mathrm{kg} \text {, } \\
\text { p.o. for } 14 \text { days }\end{array}$ & $\begin{array}{l}\text { Reduction of neuronal } \\
\text { death and seizure intensity, } \\
\text { reduction MLKL and RIP- } \\
1 \text {, and increased beclin } \\
\text { LC3B-1 and II/I LC3B }\end{array}$ & CN105596357 \\
\hline 2016 & $\begin{array}{l}\text { Chen Tianrui et al./ } \\
\text { Yunnan Ruifen } \\
\text { Biological Tech Co } \\
\text { Ltd }(\mathrm{CN})\end{array}$ & $\begin{array}{l}\text { A61K36/60 } \\
\text { A61P25/08 }\end{array}$ & Industrial hemp & $\begin{array}{l}\text { Ethanol extract of } \\
\text { Cannabis }\end{array}$ & $\begin{array}{l}\text { PTZ (100 mg/kg, s.c.) in } \\
\text { mice }\end{array}$ & $\begin{array}{l}\text { Latency seizure and } \\
\text { mortality }\end{array}$ & 20 mg/kg, i.p. & $\begin{array}{l}\text { Increased latency seizure } \\
\text { and mortality latency }\end{array}$ & CN106074708 \\
\hline 2016 & $\begin{array}{l}\text { Shan Weiguan et al./ } \\
\text { Zhejiang Conba } \\
\text { Pharmaceutical Co Ltd } \\
\text { and } \\
\text { University Zhejiang } \\
\text { Technology (CN) }\end{array}$ & $\begin{array}{l}\text { A61K36/16 } \\
\text { A61P25/08 }\end{array}$ & Ginkgo biloba & Ethanol extract & $\begin{array}{l}\text { Pilocarpine ( } 20 \mathrm{mg} / \mathrm{kg} \text {, } \\
\text { lumbar) and lithium } \\
\text { chloride ( } 3 \mathrm{mmol} / \mathrm{kg} \text {, } \\
\text { lumbar) in rats }\end{array}$ & $\begin{array}{l}\text { Racine scale, EEG and } \\
\text { immunohistochemistry }\end{array}$ & $\begin{array}{l}40 \mathrm{mg} / \mathrm{kg}, \mathrm{p} . \mathrm{o} . \\
\text { for } 4 \text { or } 8 \text { weeks }\end{array}$ & $\begin{array}{l}\text { Reduction of seizure and } \\
\text { intensity, improved EEG, } \\
\text { increased BDNF, VEGF } \\
\text { and GDNF protein }\end{array}$ & CN105287657 \\
\hline 2017 & $\begin{array}{l}\text { Guo Liangjun et al. } \\
\text { (CN) }\end{array}$ & $\begin{array}{l}\mathrm{A} 61 \mathrm{~K} 36 / 80 \\
\mathrm{~A} 61 \mathrm{P} 25 / 08\end{array}$ & $\begin{array}{c}\text { Monochasma sauatieri } \\
\text { Franch }\end{array}$ & Ethanol extract & $\begin{array}{l}\text { PTZ }(100 \mathrm{mg} / \mathrm{kg} \text {, s.c. }) \\
\text { and MES }(100 \mathrm{~V} \text { for } \\
0.3 \mathrm{~s}) \text { in mice }\end{array}$ & $\begin{array}{l}\text { Seizure incidence and } \\
\text { mortality }\end{array}$ & $\begin{array}{l}1.25,2.25,3.25 \\
\mathrm{mg} / \mathrm{kg} \text {, p.o., for } \\
7 \text { days }\end{array}$ & $\begin{array}{l}\text { Seizure and mortality } \\
\text { reduction }\end{array}$ & CN106692436 \\
\hline 2017 & $\begin{array}{l}\text { Ma Yuying et a./ } \\
\text { University Chengdu } \\
\text { Traditional Chinese } \\
\text { Medicine }(\mathrm{CN}) \\
\end{array}$ & $\begin{array}{l}\text { A61K36/8988 } \\
\text { A61P25/08 }\end{array}$ & Gastrodia elata & Submicron powder & $\begin{array}{l}\text { PTZ (62.5 mg/kg, i.p.) in } \\
\text { mice }\end{array}$ & $\begin{array}{l}\text { Number of seizures } \\
\text { and mortality }\end{array}$ & $\begin{array}{c}0.3,0.6,1.2 \\
\mathrm{~g} / \mathrm{kg}, \text { p.o., for } 5 \\
\text { days }\end{array}$ & $\begin{array}{l}\text { Seizure and mortality } \\
\text { reduction }\end{array}$ & CN106334100 \\
\hline 2018 & $\begin{array}{c}\text { De Witte Peter A M et } \\
\text { al. (ES) }\end{array}$ & $\begin{array}{l}\text { A61K36/9066 } \\
\text { A61P25/08 }\end{array}$ & $\begin{array}{c}\text { Bisabolene } \\
\text { sesquiterpenoid }\end{array}$ & $\begin{array}{l}\text { Isolated from } \\
\text { turmeric oil }\end{array}$ & $\begin{array}{l}\text { PTZ }(20 \mathrm{mM}) \text { in } \\
\text { zebrafish larvae }\end{array}$ & Larval movement & $\begin{array}{l}2.5,5 \text { and } 10 \\
\mathrm{pg} / \mathrm{mL} \text { (not } \\
\text { reported) }\end{array}$ & Seizure reduction & ES2661844 \\
\hline 2018 & $\begin{array}{c}\text { Cao Gang et al./ } \\
\text { University Zhejiang } \\
\text { Chinese Medical (CN) }\end{array}$ & $\begin{array}{l}\text { A61K36/87 } \\
\text { A61P25/08 }\end{array}$ & Trifolium repens & $\begin{array}{l}\text { Ethanol extract } \\
\text { decoction of pieces } \\
\text { of } T \text {. repens }\end{array}$ & $\begin{array}{l}\text { Febrile convulsion (45 } \\
{ }^{\circ} \mathrm{C} \text { of water baths for } 5 \\
\text { minutes continuous) in } \\
\text { rats }\end{array}$ & Seizure latency & $\begin{array}{l}20,40 \text { and } 80 \\
\mathrm{mg} / \mathrm{kg} \text {, p.o., for } \\
3 \text { days }\end{array}$ & Reduced seizure latency & CN108186812 \\
\hline 2018 & $\begin{array}{l}\text { Cai Decheng et al. } \\
\text { (CN) }\end{array}$ & $\begin{array}{l}\mathrm{A} 61 \mathrm{~K} 36 / 28 \\
\mathrm{~A} 61 \mathrm{P} 25 / 08\end{array}$ & Tagetespatula $\mathrm{L}$. & Ethanol extract & $\begin{array}{l}\text { PTZ ( } 9 \mathrm{mg} / \mathrm{mL} \text {, i.p. }) \text { in } \\
\text { mice }\end{array}$ & Racine scale & $\begin{array}{l}400 \text { and } 800 \\
\mathrm{mg} / \mathrm{kg} \text {, p.o. }\end{array}$ & $\begin{array}{c}\text { Reduced seizure and } \\
\text { increased mortality latency }\end{array}$ & CN107865896 \\
\hline 2018 & Stott Colin et al./ & A61K36/185 & Cannabidiolic acid & Purified extract & $\begin{array}{l}\text { PTZ (90 mg/kg, i.p.) in } \\
6\end{array}$ & Seizure latency, & $100 \mathrm{mg} / \mathrm{kg}$ (not & Increased seizure latency, & US2018228751 \\
\hline
\end{tabular}


Research, Society and Development, v. 11, n.2, e40311225860, 2022

(CC BY 4.0) | ISSN 2525-3409 | DOI: http://dx.doi.org/10.33448/rsd-v11i2.25860

\begin{tabular}{|c|c|c|c|c|c|c|c|c|c|}
\hline & Gw Pharma Ltd (GB) & A61P25/08 & & of Cannabis & rats & $\begin{array}{c}\text { percentage, seizure } \\
\text { severity and mortality }\end{array}$ & reported) & $\begin{array}{l}\text { reduced seizure severity } \\
\text { and mortality }\end{array}$ & (A1) \\
\hline 2018 & $\begin{array}{c}\text { Whalley Benjamin et } \\
\text { al./ } \\
\text { Gw Pharma Ltd (GB) }\end{array}$ & $\begin{array}{l}\text { A61K36/185 } \\
\text { A61P25/08 }\end{array}$ & Cannabidivarin & Not reported & $\begin{array}{l}\text { PTZ (80 mg/kg, i.p.) in } \\
\text { rats }\end{array}$ & $\begin{array}{c}\text { Seizure severity and } \\
\text { mortality }\end{array}$ & $\begin{array}{l}100 \text { and } 200 \\
\mathrm{mg} / \mathrm{kg} \text {, i.p. }\end{array}$ & $\begin{array}{l}\text { Reduced seizure severity } \\
\text { and mortality }\end{array}$ & AU2018217303 \\
\hline 2019 & $\begin{array}{l}\text { Yang Bingyou et al./ } \\
\text { University } \\
\text { Heilongjiang Chinese } \\
\text { Medicine }(\mathrm{CN}) \\
\end{array}$ & $\begin{array}{c}\mathrm{A} 61 \mathrm{~K} 36 / 233 \\
\mathrm{~A} 61 \mathrm{P} 25 / 08\end{array}$ & Bupleurum chinense & $\begin{array}{c}\text { Oil extracted by } \\
\text { steam distillation } \\
\text { and ethanol extract }\end{array}$ & $\begin{array}{l}\text { PTZ }(60 \mathrm{mg} / \mathrm{kg} \text {, i.p. }) \text { in } \\
\text { mice and kainate acid } \\
(0.5 \mu \mathrm{g} / \mu \mathrm{L} \text {, i.c.v. }) \text { in rats }\end{array}$ & $\begin{array}{l}\text { Racine scale, seizure } \\
\text { duration and mortality }\end{array}$ & $\begin{array}{c}200 \text { and } 400 \\
\mathrm{mg} / \mathrm{kg} \text {, i.g. for } 7 \\
\text { days }\end{array}$ & $\begin{array}{l}\text { Reduction in seizure } \\
\text { duration, intensity, and } \\
\text { mortality }\end{array}$ & CN110522777 \\
\hline 2020 & $\begin{array}{l}\text { Stott Colin et al./ } \\
\text { Gw Res Ltd (GB) }\end{array}$ & $\begin{array}{l}\mathrm{A} 61 \mathrm{~K} 36 / 185 \\
\mathrm{~A} 61 \mathrm{P} 25 / 08\end{array}$ & $\begin{array}{l}\text { 7-hydroxy-cannabidol } \\
\text { and/or 7-hydroxy- } \\
\text { cannabidivarin } \\
\end{array}$ & $\begin{array}{l}\text { Pure, isolated or } \\
\text { synthetic form }\end{array}$ & $\begin{array}{l}\text { PTZ (70 or } 80 \mathrm{mg} / \mathrm{kg} \text {, } \\
\text { i.p.) in rats }\end{array}$ & $\begin{array}{c}\text { Latency seizure, } \\
\text { severity and mortality }\end{array}$ & $\begin{array}{l}200 \text { and } 100 \\
\mathrm{mg} / \mathrm{kg} \text {, i.p. }\end{array}$ & $\begin{array}{l}\text { Increased seizure latency, } \\
\text { reduced seizure severity } \\
\text { and mortality }\end{array}$ & EP3639814 \\
\hline 2020 & $\begin{array}{l}\text { Geoffrey Guy et al./ } \\
\text { Gw Res Ltd (GB) }\end{array}$ & $\begin{array}{l}\mathrm{A} 61 \mathrm{~K} 36 / 185 \\
\mathrm{~A} 61 \mathrm{P} 25 / 08\end{array}$ & Cannabidiol-C4 & $\begin{array}{l}\text { Highly purified } \\
\text { plant extract } \\
\text { (Cannabis) or } \\
\text { synthetic } \\
\end{array}$ & $\begin{array}{c}\mathrm{MES}(50 \mathrm{~mA}, 0.4 \mathrm{~s}, 50 \\
\mathrm{Hz}) \text { in mice }\end{array}$ & Number of seizures & $\begin{array}{l}100 \text { e } 200 \\
\mathrm{mg} / \mathrm{kg} \text {, i.p. }\end{array}$ & $\begin{array}{c}\text { Decrease in the number of } \\
\text { seizures }\end{array}$ & GB2579179 \\
\hline 2020 & $\begin{array}{c}\text { Belousov Mikhail et } \\
\text { al./ } \\
\text { Fed Gosudarstvennoe } \\
\text { Byudzhetnoe } \\
\text { Nauchnoe } \\
\text { Uchrezhdenie Tomskij } \\
\text { Natsionalnyj } \\
\text { Issledovatelskij } \\
\text { Meditsin (Ru) } \\
\end{array}$ & $\begin{array}{l}\text { A61K36/45 } \\
\text { A61P25/08 }\end{array}$ & Empetrum nigrum $\mathrm{L}$. & $\begin{array}{l}\text { Acetone fraction of } \\
\text { the dry chloroform } \\
\text { extract }\end{array}$ & $\begin{array}{l}\text { Strychnine }(1.5 \mathrm{mg} / \mathrm{kg} \text {, } \\
\text { s.c.) in mice }\end{array}$ & $\begin{array}{l}\text { Life expectancy and } \\
\text { percentage of survival }\end{array}$ & $\begin{array}{l}150 \mathrm{mg} / \mathrm{kg}, \text { p.o., } \\
\text { for } 5 \text { days }\end{array}$ & $\begin{array}{l}\text { Increased life expectancy } \\
\text { and survival }\end{array}$ & RU2714687 \\
\hline 2020 & $\begin{array}{c}\text { Sun Hong et al./ } \\
\text { The Second Affiliated } \\
\text { Hospital Of College } \\
\text { Of Medicine Of Xian } \\
\text { Jiaotong University } \\
\text { (CN) }\end{array}$ & $\begin{array}{l}\text { A61K36/83 } \\
\text { A61P25/08 }\end{array}$ & Stellera chamaejasme & $\begin{array}{l}\text { Extraction method } \\
\text { of total alkaloids }\end{array}$ & $\begin{array}{l}\text { Pilocarpine }(30 \mathrm{mg} / \mathrm{kg} \text {, } \\
\text { i.p.) and lithium chloride } \\
(180 \mathrm{mg} / \mathrm{kg} \text {. i.p. }) \text { in rats }\end{array}$ & $\begin{array}{c}\text { Racine scale and } \\
\text { immunofluorescence } \\
(\mathrm{CD} 40)\end{array}$ & $\begin{array}{c}50,100 \text { and } 200 \\
\mathrm{mg} / \mathrm{kg} \text { (not } \\
\text { reported) for } 7 \\
\text { days }\end{array}$ & $\begin{array}{l}\text { Reduced of neuronal } \\
\text { damage (reduced CD40) }\end{array}$ & CN110960599 \\
\hline
\end{tabular}

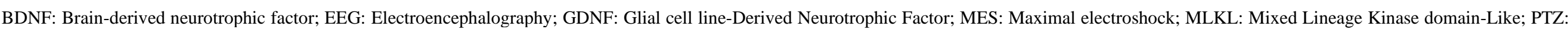

Pentylenetetrazole; RIP-1: Receptor Interacting Protein; VEGF: Vascular Endothelial Growth Factor. Source: Prepared by the authors. 
In 2016, 3 patents using compounds initially obtained from ethanolic extracts were filed in China (Chen \& Hu, 2016; $\mathrm{Hu}$ et al., 2016; Shan et al., 2016). Ethanol is a commonly used extraction solvent due to its safety and ability to extract a variety of active compounds from plants (Sabedra et al., 2017). Hu Kai and collaborators report the purification of aucubin, an iridoid glycoside obtained from the ethanolic extract of Eucommia ulmoides via ultrasound. Aucubin treatment treatment (5 and $10 \mathrm{mg} / \mathrm{kg}$ orally) administered for 14 days reduced neuronal death by reduced mixed lineage kinase domain-like (MLKL) domains and receptor-interacting protein kinase 1 (RIP-1) proteins. When induced by pilocarpine (20 mg/kg, intraperitoneal (i.p.)) and lithium chloride (125 mg/kg, i.p.), animals treated with aucubin increased the expression of beclin LC3B-1 and the levels of the structural proteins of autophagosomal membrane LC3B-II/I, suggesting a potential neuroprotective effect (Hu et al., 2016). Similarly, Yunnan Ruifen Biological Tech Co Ltd also discloses in their invention several methods for obtaining ethanol extract from Industrial hemp. Industrial hemp. is a plant of the species Cannabis sativa L. used in the industry due to its high nutritional value and potential functional characteristics (Farinon et al., 2020). Treatment administered at $20 \mathrm{mg} / \mathrm{kg}$, i.p., of the ethanolic extract have demonstrated an increase in seizure latency and mortality latency in mice induced by PTZ (100 mg/kg, subcutaneous (s.c.)) (Chen \& Hu, 2016).

Zhejiang Conba Pharmaceutical Co Ltd and the Zhejiang University of Technology report the obtention of Ginkgo biloba ethanolic extract with $11 \%$ lactones, $40 \%$ flavonoids and $48 \%$ procyanidins. Ginkgo biloba is a medicinal plant used in the treatment of Alzheimer's disease, cognitive impairment, diabetes, hypertension and dyslipidemia (Eisvand et al., 2020; G. Yang et al., 2016). The inventors were able to show that a more pronounced antiepileptic effect is achieved when the extract formulation has a higher content of procyanidin than the total flavonoids. Studies using this extract formulation for 4 or 8 weeks at $40 \mathrm{mg} / \mathrm{kg}$, orally, also reduced the seizure incidence and increased the expression of proteins responsible for promoting differentiation of neuronal cells, including brain-derived neurotropic factor (BDNF), vascular endothelial factor (VEGF) and glial cell line-derived neurotrophic factor (GDNF), after administration of lithium chloride (3 mmol/ $\mathrm{kg}, \mathrm{lumbar})$ and pilocarpine (20 mg/kg, lumbar) (Shan et al., 2016).

Following, in 2017 two patents employing ethanolic extracts and ultrafine powder have been disclosed (Guo et al., 2017; Ma et al., 2017). Guo Liangium and collaborators disclose the invention of a drug based on different methods of acquiring Monochasma savatieri Franch ethanol extract. Studies have shown that treatment with this ethanolic extract at doses of 1.25 to $3.25 \mathrm{~g} / \mathrm{kg}$, p.o. for 7 days reduced seizures and mortality in mice subjected to the administration of PTZ (100 mg/kg, s.c.) and MES (100 V for 0.3s) (Guo et al., 2017). Similarly, patent developed by Chengdu University of Traditional Chinese Medicine discloses a preparation of ultrafine powder from Gastrodia elata. Gastrodia elata is a traditional Chinese medicine known for its broad pharmacotherapeutic properties to treat central nervous system disorders, including epilepsy (Liu et al., 2018). Inventors claims include reduced seizure and mortality of animals when subjected to PTZ at $62.5 \mathrm{mg} / \mathrm{kg}$, i.p. upon oral administration of the ultrafine powder at $0.3,0.6,1.2 \mathrm{~g} / \mathrm{kg}$ doses, after a period of 5 days administration, (Ma et al., 2017).

Five patent applications were found in 2018 (Cai \& Ran, 2018; Cao \& Zhang, 2018; De Witte Petter et al., 2018; Stott et al., 2018; Whalley et al., 2018). Among the patents, the invention filed by De Witte Petter et al. ( 2018) reports the evaluation of the bisabolene bioactive compound isolated from turmeric oil through hydrodistillation in a Clevenger type apparatus. The authors state that the pharmacotherapeutic effect of bisabolene at doses of $2.5,5$ and $10 \mathrm{pg} / \mathrm{mL}$ appears to reduce induced convulsive movements after PTZ administration (20 mM) (De et al., 2018). Another patent invention disclosed, includes the obtention of the extract of Trifolium repens by decoction extraction method (Cao \& Zhang, 2018). Trifolium repens is a plant with antioxidant, anti-inflammatory, analgesic and antimicrobial effects also used in traditional Chinese medicine (Ahmad \& Zeb, 2020). The invention filed by the Zhejiang Chinese Medical University suggests administration of the extract for 3 days at doses of 20,40 and $80 \mathrm{mg} / \mathrm{kg}$, orally. The Trifolium repens extract formulation has proven to be effective against febrile seizures in rats (Cao \& Zhang, 2018). Similarly, another patent application employing plant extracts in 
antiepileptic drugs includes the use of total flavonoids from the ethanolic extract of Tagetespatula L.. The use of these phytochemicals at 400 and $800 \mathrm{mg} / \mathrm{kg}$, p.o. accounted for reducing the seizure and increasing the latency of death in mice also induced by PTZ administration (9 mg/mL, i.p.) (Cai \& Ran, 2018).

Over the last few years increased interest in cannabis-based products has been observed within the clinical pharmacology sector for its properties in reducing the frequency of convulsive seizures (Perucca, 2017; Russo \& Marcu, 2017). Two patents filed in 2018 by Gw Pharma Ltd refer to methods of obtaining purified cannabinoid compounds from Cannabis. Cannabidiolic acid (100 mg/kg) demonstrated anticonvulsant effects throughout increased seizure latency, as well as reducing severity and mortality in rats subjected to administration of PTZ (90 mg/kg, i.p.) (Stott et al., 2018). Similarly, the same company also report that the use of Cannabidivarin (100 and $200 \mathrm{mg} / \mathrm{kg}$, i.p.), an analogue of cannabidiol, which also reduced seizure severity and mortality in the PTZ models ( $80 \mathrm{mg} / \mathrm{kg}$, i.p.) (Whalley et al., 2018).

In 2019, only one patent belonging to the Heilongjiang University of Chinese Medicine was found (B. Yang et al., 2019). The treatment with the Bupleurum chinense ethanol extract and its essential oil (obtained by steam distillation) at 200 and $400 \mathrm{mg} / \mathrm{kg}$, i.p. reduced seizure and duration in experimental animal models after the administration of PTZ (60 mg/kg, ip) and kainate acid $(0.5 \mu \mathrm{g} / \mu \mathrm{L}$, i.c.v.). In addition, the extract and essential oil showed neuroprotective effects in hippocampal cells, suggesting that these compounds may be a promising alternative to the treatment of seizures (B. Yang et al., 2019).

Finally, in 2020, 4 patent inventions were found (Belousov et al., 2020; Geoffrey et al., 2020; Stott et al., 2020; Sun et al., 2020). The first patent invention, deposited by the company Gw Res Ltd, claims the isolation for the first time of the compounds 7-hydroxy-cannabidol and 7-hydroxy-cannabidivarin (100 and $200 \mathrm{mg} / \mathrm{kg}$, i.p.), which have shown to act on the nervous system increasing seizure latency time, and reducing the severity and mortality of animals submitted to PTZ (70 or 80 $\mathrm{mg} / \mathrm{kg}$, i.p.) (Stott et al., 2020). This same company, also obtained another cannabinoid compound derived from Cannabis, Cannabidiol-C4. Treatment of mice with Cannabidiol-C4 at 100 and $200 \mathrm{mg} / \mathrm{kg}$, i.p. was responsible for reducing the number of seizures induced to electrical stimulation (Geoffrey et al., 2020).

Empetrum nigrum L. is a plant that has been widely employed in the treatment of epilepsy, paralysis and as a sedative in folk medicine (Jurikova et al., 2016). The third patent registered by Belousov Mikhail and colleagues, refers to a method to obtain an acetonic fraction from the dry chloroform extract of the plant Empetrum nigrum L. The preventive treatment with $150 \mathrm{mg} / \mathrm{kg}$, orally, for 5 days, provided increased life expectancy and survival in mice induced with strychnine (1.5 mg/kg, s.c.) (Belousov et al., 2020). The last patent was filed by The Second Affiliated Hospital Of Xi'an Jiaotong University College Of Medicine and describes ways of obtaining the flavonoid fraction of the Stellera chamaejasme plant. The authors attest that the flavonoids present in S. chamaejasme are capable of reducing neuronal damage caused by the administration of Pilocarpine (30 mg/kg, i.p.) and lithium chloride (180 mg/kg. i.p.) in rats (Sun et al., 2020). Thus, the natural products obtained from plants are effective alternatives in the treatment of partial and generalized epilepsy.

\section{Discussion}

In this review, we assessed the published patent inventions referring to natural compounds in the form of extracts, essential oils and isolated compounds with proven anticonvulsant properties, filed between the years of 2015 and 2020.10 patents $(52.63 \%)$ reported methods of obtaining plant extracts, 1 patent $(5.26 \%)$ disclosed an essential oil and 8 patents $(42.11 \%)$ described purified plant compounds. These findings reinforce the idea that the use of natural products can be a promising alternative for the treatment of pathologies, including epilepsy (Elliott et al., 2020; Quintans-Júnior et al., 2008).

In view of the pharmacological potential of medicinal plants and the reduction of adverse effects, investment in the scientific production of these compounds has increased. Natural compounds derived from plants have been extensively studied 
and are commercially available. Sativex ${ }^{\circledR}$, for example, was the first medicine produced based on Cannabis. Despite being initially indicated for multiple sclerosis, studies have shown the effectiveness of its active principle on epilepsy (Filloux, 2015). Recently, another drug containing cannabidiol, produced in Brazil, with potential indication for the treatment of refractory epilepsy has been approved. Unlike Sative ${ }^{\circledR}$, the formulation containing only cannabidiol has fewer side effects due to the absence of psychoactive substances, such as $\Delta^{9}$-THC (Gaston \& Friedman, 2017).

Moreover, all purified cannabinoid compounds have been patented by the pharmaceutical industry Gw Pharma Ltd, which is a pioneer in the search for new pharmaceutical compositions derived from Cannabis. Phytocannabinoids cannabidiolic acid, cannabidivarin, 7-hydroxy-cannabidol, 7-hydroxy-cannabidivarin and cannabidiol-C4 act on cannabinoid receptor 1 (CB1) and cannabinoid receptor 2 (CB2) promotes reduction of neuronal excitability in the hippocampus. The biochemical interaction of these receptors results in the regulation and release of neurotransmitters, including glutamate present on the surface of brain cells (Gaston \& Friedman, 2017; O'Connell et al., 2017; Rosenberg et al., 2017; Yao et al., 2019).

Although most of the patents in this review do not report the biochemical interactions of the compounds studied, a few mechanisms of action can be suggested. Salvia miltiorrhiza, for example, can exert its anticonvulsant effect through agonistic action on gamma-aminobutyric acid $\left(\mathrm{GABA}_{\mathrm{A}}\right)$ receptors (Lin et al., 2021). In addition, this specie can exert neuroprotective effects through the modulation of inflammatory mediators and oxidative stress ( $\mathrm{Su}$ et al., 2015). Aucubin, studied in the patent by Hu Kai et al. (2016), is responsible for lessening neuronal damage by reducing Mixed Lineage Kinase domain-Like (MLKL) domains, RIP-1 receptors, Beclin-1 and LC3BII/LC3BI proteins and inflammation markers including

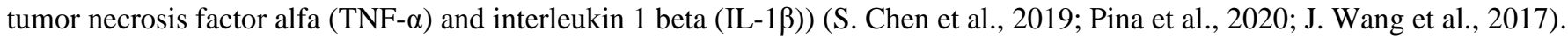
Similarly, Ginkgo biloba extract is also recognized for its neuroprotective ability to reduce neuronal damage and oxidative stress (Yan et al., 2020; D. Yu et al., 2020). Likewise, the anticonvulsant effect of Gastrodia elata extract studied in patent Ma et al. (2017) is known to alter the amount of GABA neurotransmitters receptors and to reduce neuronal damage induced in seizure models (Matias et al., 2016). The anticonvulsant effects of Monochasma sauatieri Franch extract claimed in patent Guo et al. (2017) can be related to its antioxidant ability to increase the enzymatic activities of superoxide dismutase (SOD) and glutathione (GSH), as well as to decrease the content of malondialdehyde (MDA) (Shi et al., 2013).

\section{Conclusion}

Thus, all of these compounds are promising alternatives due to their neuroprotective potential and mechanisms of action on $\mathrm{GABA}_{\mathrm{A}}, \mathrm{CB} 1$ and $\mathrm{CB} 2$ receptors. In view of this, the development of new plant-based pharmaceutical compositions is a promising alternative for the treatment of epilepsy, especially for patients suffering from drug-resistant epilepsy. However, there are several limitations due to the initial state of these surveys. On the other hand, these findings are crucial for carrying out safety and efficacy studies using the tested substances.

\section{Acknowledgments}

We thank grants from the Fundação de Apoio à Pesquisa e Inovação Tecnológica do Estado de Sergipe (FAPITEC/SE), Conselho Nacional de Desenvolvimento Científico e Tecnológico (CNPq/Brazil) and Coordenação de Aperfeiçoamento de Pessoal de Nível Superior (CAPES/Brazil). 


\section{References}

Ahmad, S., \& Zeb, A. (2020). Phytochemical profile and pharmacological properties of Trifolium repens. Journal of Basic and Clinical Physiology and Pharmacology. https://doi.org/10.1515/jbcpp-2020-0015

Auditeau, E., Chassagne, F., Bourdy, G., Bounlu, M., Jost, J., Luna, J., Ratsimbazafy, V., Preux, P.-M., \& Boumediene, F. (2019). Herbal medicine for epilepsy seizures in Asia, Africa and Latin America: A systematic review. Journal of Ethnopharmacology, 234, 119-153. https://doi.org/10.1016/j.jep.2018.12.049

Beghi, E. (2020). The Epidemiology of Epilepsy. Neuroepidemiology, 54(2), 185-191. https://doi.org/10.1159/000503831

Belousov, M. V., Yusubov, M. S., Gurev, A. M., Bezverkhnyaya, E. A., Kadyrova, T. V., Ermilova, E. V., Suslov, N. I., Poveteva, T. N., Nesterova, Y. V., Afanaseva, O. G., Kulpin, P. V., \& Shaposhnikov, K. V. (2020). Agent Having Anticonvulsant Activity (Patent No RU2714687 (C1)). https://worldwide.espacenet.com/publicationDetails/biblio?FT=D\&date=20200219\&DB=EPODOC\&locale=en_EP\&CC=RU\&NR=2714687C1\&KC=C1\&N $\mathrm{D}=1$

Bulaj, G., Ahern, M. M., Kuhn, A., Judkins, Z. S., Bowen, R. C., \& Chen, Y. (2016). Incorporating Natural Products, Pharmaceutical Drugs, Self-Care and Digital/Mobile Health Technologies into Molecular-Behavioral Combination Therapies for Chronic Diseases. Current Clinical Pharmacology, 11(2), 128145. https://doi.org/10.2174/1574884711666160603012237

Byun, J.-I., Kim, D. W., Kim, K. T., Yang, K. I., Lee, S.-T., Seo, J.-G., No, Y. J., Kang, K. W., Kim, D., Kim, J. M., \& Cho, Y. W. (2020). Treatment of epilepsy in adults: Expert opinion in South Korea. Epilepsy \& Behavior, 105, 106942. https://doi.org/10.1016/j.yebeh.2020.106942

Cai, D., \& Ran, X. (2018). Application of total flavonoid extract of tagetes patula in antiepileptic drug (Patent $\mathrm{N}^{\circ}$ CN107865896 (A)). https://worldwide.espacenet.com/publicationDetails/biblio?FT=D\&date=20180403\&DB=EPODOC\&locale=en_EP \&CC $=\mathrm{CN} \& N R=107865896 \mathrm{~A} \& \mathrm{KC}=\mathrm{A} \& \mathrm{~N}$ $\mathrm{D}=1$

Cao, G., \& Zhang, J. (2018). Application of radix tetrastigme extract in preparation of febrile convulsion resisting drug (Patent $\mathrm{N}^{\circ}$ CN108186812 (A)). https://worldwide.espacenet.com/publicationDetails/biblio?FT=D\&date=20180622\&DB=EPODOC\&locale=en_EP\&CC $=C N \& N R=108186812 A \& K C=A \& N$ $\mathrm{D}=1$

Catchpool, M., Dalziel, K., Mahardya, R. T. K., \& Harvey, A. S. (2019). Cost-effectiveness of epileptic surgery compared with medical treatment in children with drug-resistant epilepsy. Epilepsy \& Behavior, 97, 253-259. https://doi.org/10.1016/j.yebeh.2019.04.004

Chatterjee, A., Nair, R., Gandeti, R., Puppala, G. K., Chandran, V., Gorthi, S. P., \& Radhakrishnan, K. (2020). Socioeconomic consequences of drug-resistant epilepsy in an adult cohort from southern India. Epilepsy \& Behavior, 110, 107173. https://doi.org/10.1016/j.yebeh.2020.107173

Chen, S., Zeng, X., Zong, W., Wang, X., Chen, L., Zhou, L., Li, C., Huang, Q., Huang, X., Zeng, G., Hu, K., \& Ouyang, D.-S. (2019). Aucubin Alleviates Seizures Activity in Li-Pilocarpine-Induced Epileptic Mice: Involvement of Inhibition of Neuroinflammation and Regulation of Neurotransmission. Neurochemical Research, 44(2), 472-484. https://doi.org/10.1007/s11064-018-2700-y

Chen, T., \& Hu, J. (2016). Application of cannabinoid in preparing medicines for treating epilepsy (Patent $\mathrm{N}^{\circ}$ CN106074708 (A)). https://worldwide.espacenet.com/publicationDetails/biblio?FT =D\&date=20161109\&DB=\&locale=en_EP\&CC=CN\&NR=106074708A\&KC=A\&ND=4

Chen, Z., Brodie, M. J., Liew, D., \& Kwan, P. (2018). Treatment Outcomes in Patients With Newly Diagnosed Epilepsy Treated With Established and New Antiepileptic Drugs: A 30-Year Longitudinal Cohort Study. JAMA Neurology, 75(3), 279-286. https://doi.org/10.1001/jamaneurol.2017.3949

da Fonsêca, D. V., da Silva Maia Bezerra Filho, C., Lima, T. C., de Almeida, R. N., \& de Sousa, D. P. (2019). Anticonvulsant Essential Oils and Their Relationship with Oxidative Stress in Epilepsy. Biomolecules, 9(12). https://doi.org/10.3390/biom9120835

De, W. P. a M., Esguerra, C. V., Crawford, A. D., \& Orellana, P. A. M. (2018). Anticonvulsant Activity of Turmeric Oil and Bisabolene Sesquiterpenoids (Patent $\quad \mathrm{N}^{\mathrm{o}} \quad$ ES2661844 (T3)). https://worldwide.espacenet.com/publicationDetails/biblio?FT=D\&date=20180404\&DB=EPODOC\&locale=en_EP\&C $\mathrm{C}=\mathrm{ES} \& \mathrm{NR}=2661844 \mathrm{~T} 3 \& \mathrm{KC}=\mathrm{T} 3 \& \mathrm{ND}=1$

Deivasigamani, M., Kannan, N., Sekar, N., \& Lakshmanan, H. (2021). Safety assessment of ethanolic root extract of Zaleya decandra (EEZD) in Wistar rats. Regulatory Toxicology and Pharmacology, 119, 104822. https://doi.org/10.1016/j.yrtph.2020.104822

Ding, S., Li, X., Hua, Y., Dong, F., Lin, J., Du, Y., Shen, J., Xia, N., Zhu, Z., Wang, X., Zheng, R., \& Xu, H. (2019). Risk factors for suicidal tendency in adult patients with epilepsy in China. Epilepsy \& Behavior, 97, 118-122. https://doi.org/10.1016/j.yebeh.2019.06.006

Eisvand, F., Razavi, B. M., \& Hosseinzadeh, H. (2020). The effects of Ginkgo biloba on metabolic syndrome: A review. Phytotherapy Research: PTR, 34(8), 1798-1811. https://doi.org/10.1002/ptr.6646

Elliott, J., DeJean, D., Potter, B. K., Coyle, D., Clifford, T., McCoy, B., \& Wells, G. A. (2020). Neurologists' perspectives on medical cannabis for pediatric drug-resistant epilepsy in Canada: A qualitative interview study. Seizure, 78, 118-126. https://doi.org/10.1016/j.seizure.2020.04.002

Farinon, B., Molinari, R., Costantini, L., \& Merendino, N. (2020). The Seed of Industrial Hemp (Cannabis sativa L.): Nutritional Quality and Potential Functionality for Human Health and Nutrition. Nutrients, 12(7), 1935. https://doi.org/10.3390/nu12071935

Filloux, F. M. (2015). Cannabinoids for pediatric epilepsy? Up in smoke or real science? Translational Pediatrics, 4(4), 271-282. https://doi.org/10.3978/j.issn.2224-4336.2015.10.03

Fisher, R. S., Cross, J. H., French, J. A., Higurashi, N., Hirsch, E., Jansen, F. E., Lagae, L., Moshé, S. L., Peltola, J., Roulet Perez, E., Scheffer, I. E., \& Zuberi, S. M. (2017). Operational classification of seizure types by the International League Against Epilepsy: Position Paper of the ILAE Commission for Classification and Terminology. Epilepsia, 58(4), 522-530. https://doi.org/10.1111/epi.13670 
Fisher, R. S., van Emde Boas, W., Blume, W., Elger, C., Genton, P., Lee, P., \& Engel, J. (2005). Epileptic seizures and epilepsy: Definitions proposed by the International League Against Epilepsy (ILAE) and the International Bureau for Epilepsy (IBE). Epilepsia, 46(4), 470-472. https://doi.org/10.1111/j.00139580.2005.66104.x

Gaston, T. E., \& Friedman, D. (2017). Pharmacology of cannabinoids in the treatment of epilepsy. Epilepsy \& Behavior, 70, 313-318. https://doi.org/10.1016/j.yebeh.2016.11.016

Geoffrey, G., Volker, K., Benjamin, W., Royston, G., Jacqueline, C., Amesha, P., \& Hannah, S. (2020). Cannabidiol-type cannabinoid compound (Patent N ${ }^{\circ}$ GB2579179 (A)). https://worldwide.espacenet.com/publicationDetails/biblio?FT=D\&date=20200617\&DB=EPODOC\&locale=en_EP\&CC=GB\&NR=2579 $179 \mathrm{~A} \& \mathrm{KC}=\mathrm{A} \& \mathrm{ND}=1$

Guerreiro, C. A. M. (2016). Epilepsy: Is there hope? The Indian Journal of Medical Research, 144(5), 657-660. https://doi.org/10.4103/ijmr.IJMR_1051_16

Guo, L., Zheng, W., Tan, X., \& Wang, X. (2017). Application of Monochasma sheareri extract (Patent $\mathrm{N}^{\circ}$ CN106692436 (A)). https://worldwide.espacenet.com/publicationDetails/biblio?FT=D\&date=20170524\&DB=EPODOC\&locale=en_EP\&CC=CN\&NR=106692436A\&KC=A\&N $\mathrm{D}=1$

Hu, K., Ouyang, D., Li, X., Huang, Q., Zeng, X., Zhou, L., \& Luo, W. (2016). Application of aucubin to preparation of medicine for treating or preventing epilepsy (Patent $\mathrm{N}^{\circ}$ CN105596357 (A)). https://worldwide.espacenet.com/publicationDetails/biblio?FT=D\&date=20160525\&DB=EPODOC\&locale=en_E $\mathrm{P} \& \mathrm{CC}=\mathrm{CN} \& \mathrm{NR}=105596357 \mathrm{~A} \& \mathrm{KC}=\mathrm{A} \& \mathrm{ND}=1$

Huyan, T., Li, Q., Wang, Y.-L., Li, J., Zhang, J.-Y., Liu, Y.-X., Shahid, M. R., Yang, H., \& Li, H.-Q. (2016). Anti-tumor effect of hot aqueous extracts from Sonchus oleraceus (L.) L. and Juniperus sabina L - Two traditional medicinal plants in China. Journal of Ethnopharmacology, 185, 289-299. https://doi.org/10.1016/j.jep.2016.03.044

Johnson, E. L. (2019). Seizures and Epilepsy. The Medical Clinics of North America, 103(2), 309-324. https://doi.org/10.1016/j.mcna.2018.10.002

Jurikova, T., Mlcek, J., Skrovankova, S., Balla, S., Sochor, J., Baron, M., \& Sumczynski, D. (2016). Black Crowberry (Empetrum nigrum L.) Flavonoids and Their Health Promoting Activity. Molecules (Basel, Switzerland), 21(12). https://doi.org/10.3390/molecules21121685

Kim, J.-E., \& Cho, K.-O. (2018). The Pilocarpine Model of Temporal Lobe Epilepsy and EEG Monitoring Using Radiotelemetry System in Mice. Journal of Visualized Experiments: JoVE, 132. https://doi.org/10.3791/56831

Kwan, P., Arzimanoglou, A., Berg, A. T., Brodie, M. J., Allen Hauser, W., Mathern, G., Moshé, S. L., Perucca, E., Wiebe, S., \& French, J. (2010). Definition of drug resistant epilepsy: Consensus proposal by the ad hoc Task Force of the ILAE Commission on Therapeutic Strategies. Epilepsia, 51(6), $1069-1077$. https://doi.org/10.1111/j.1528-1167.2009.02397.x

Lin, Y.-S., Peng, W.-H., Shih, M.-F., \& Cherng, J.-Y. (2021). Anxiolytic effect of an extract of Salvia miltiorrhiza Bunge (Danshen) in mice. Journal of Ethnopharmacology, 264, 113285. https://doi.org/10.1016/j.jep.2020.113285

Liu, Y., Gao, J., Peng, M., Meng, H., Ma, H., Cai, P., Xu, Y., Zhao, Q., \& Si, G. (2018). A Review on Central Nervous System Effects of Gastrodin. Frontiers in Pharmacology, 9. https://doi.org/10.3389/fphar.2018.00024

Löscher, W. (2011). Critical review of current animal models of seizures and epilepsy used in the discovery and development of new antiepileptic drugs. Seizure, 20(5), 359-368. https://doi.org/10.1016/j.seizure.2011.01.003

Löscher, W. (2017). Animal Models of Seizures and Epilepsy: Past, Present, and Future Role for the Discovery of Antiseizure Drugs. Neurochemical Research, 42(7), 1873-1888. https://doi.org/10.1007/s11064-017-2222-z

Luo, G., Liang, Q., Wang, Y., Liu, Q., De, W. P., Esguerra, C., Crawford, A., Buenafe, O., Luyten, W., \& De, B. W. (2015). Dan Shen Extracts and Compounds (Patent $\quad \mathrm{N}^{\circ} \quad$ WO2015004093 (A1)). https://worldwide.espacenet.com/publicationDetails/biblio?FT=D\&date=20150115\&DB=EPOD OC\&locale $=$ em _EP \&CC $=$ WO $\& N R=2015004093 \mathrm{~A} 1 \& \mathrm{KC}=\mathrm{A} 1 \& \mathrm{ND}=1$

Ma, Y., Yang, Z., Hu, M., \& Li, Z. (2017). Gastrodia elata superfine powder, and preparation method and use of gastrodia elata superfine powder (Patent $\mathrm{N}^{\mathrm{o}}$ CN106334100 (A)). $\mathrm{NR}=106334100 \mathrm{~A} \& \mathrm{KC}=\mathrm{A} \& \mathrm{ND}=1$

Ma, Y., Zhou, K., Fan, J., \& Sun, S. (2016). Traditional Chinese medicine: Potential approaches from modern dynamical complexity theories. Frontiers of Medicine, 10(1), 28-32. https://doi.org/10.1007/s11684-016-0434-2

Makaremi, S., Ganji, A., Ghazavi, A., \& Mosayebi, G. (2021). Inhibition of tumor growth in CT-26 colorectal cancer-bearing mice with alcoholic extracts of Curcuma longa and Rosmarinus officinalis. Gene Reports, 22, 101006. https://doi.org/10.1016/j.genrep.2020.101006

Marshall, A. (2020). Traditional Chinese Medicine and Clinical Pharmacology (p. 455-482). https://doi.org/10.1007/978-3-319-68864-0_60

Mathon, B., Bordes, A., Amelot, A., Carpentier, A., Méré, M., Dupont, S., \& Samson, S. (2020). Evaluation of psychomotor functions in patients with drugresistant epilepsy. Epilepsy \& Behavior, 106, 106985. https://doi.org/10.1016/j.yebeh.2020.106985

Matias, M., Silvestre, S., Falcão, A., \& Alves, G. (2016). Gastrodia elata and epilepsy: Rationale and therapeutic potential. Phytomedicine, 23(12), 1511-1526. https://doi.org/10.1016/j.phymed.2016.09.001

Mesraoua, B., Deleu, D., Kullmann, D. M., Shetty, A. K., Boon, P., Perucca, E., Mikati, M. A., \& Asadi-Pooya, A. A. (2019). Novel therapies for epilepsy in the pipeline. Epilepsy \& Behavior: E\&B, 97, 282-290. https://doi.org/10.1016/j.yebeh.2019.04.042

O’Connell, B. K., Gloss, D., \& Devinsky, O. (2017). Cannabinoids in treatment-resistant epilepsy: A review. Epilepsy \& Behavior, 70, 341-348. https://doi.org/10.1016/j.yebeh.2016.11.012 
Perucca, E. (2017). Cannabinoids in the Treatment of Epilepsy: Hard Evidence at Last? Journal of Epilepsy Research, 7(2), 61-76. https://doi.org/10.14581/jer.17012

Pina, L. T. S., Guimarães, A. G., Santos, W. B. da R., Oliveira, M. A., Rabelo, T. K., \& Serafini, M. R. (2020). nMonoterpenes as a perspective for the treatment of seizures: A Systematic Review. Phytomedicine, 153422. https://doi.org/10.1016/j.phymed.2020.153422

Popovych, V. I., Beketova, H. V., Koshel, I. V., Tsodikova, O. A., Kriuchko, T. A., Abaturov, A. E., Vakulenko, L. I., \& Gavrylenko, I. V. (2020). An openlabel, multicentre, randomized comparative study of efficacy, safety and tolerability of the 5 plant-Extract BNO 1012 in the Delayed Antibiotic Prescription Method in children, aged 6 to 11 years with acute viral and post-viral rhinosinusitis. American Journal of Otolaryngology, 41(5), 102564. https://doi.org/10.1016/j.amjoto.2020.102564

Quintans Júnior, L. J., Almeida, J. R. G. S., Lima, J. T., Nunes, X. P., Siqueira, J. S., Oliveira, L. E. G. de, Almeida, R. N., Athayde-Filho, P. F. de, \& Barbosa-Filho, J. M. (2008). Plants with anticonvulsant properties: A review. Revista Brasileira de Farmacognosia, 18, 798-819. https://doi.org/10.1590/S0102-695X2008000500026

Quintans-Júnior, L. J., Souza, T. T., Leite, B. S., Lessa, N. M. N., Bonjardim, L. R., Santos, M. R. V., Alves, P. B., Blank, A. F., \& Antoniolli, A. R. (2008). Phythochemical screening and anticonvulsant activity of Cymbopogon winterianus Jowitt (Poaceae) leaf essential oil in rodents. Phytomedicine: International Journal of Phytotherapy and Phytopharmacology, 15(8), 619-624. https://doi.org/10.1016/j.phymed.2007.09.018

Rosenberg, E. C., Patra, P. H., \& Whalley, B. J. (2017). Therapeutic effects of cannabinoids in animal models of seizures, epilepsy, epileptogenesis, and epilepsy-related neuroprotection. Epilepsy \& Behavior, 70, 319-327. https://doi.org/10.1016/j.yebeh.2016.11.006

Russo, E. B., \& Marcu, J. (2017). Cannabis Pharmacology: The Usual Suspects and a Few Promising Leads. Advances in Pharmacology (San Diego, Calif.), 80, 67-134. https://doi.org/10.1016/bs.apha.2017.03.004

Ryvlin, P. (2005). The modern challenges of drug resistant epilepsy. Introduction. Epileptic Disorders: International Epilepsy Journal with Videotape, 7 Suppl $1, \mathrm{~S} 1-2$.

Sabedra, C. A. L., Lissner, L. A., \& Rodrigues, L. M. (2017). Avaliação Da Metodologia De Extração De Óleo Residual Do Bagaço De Oliva. ANAIS CONGREGA MIC- Mostra de Iniciação Científica e ANAIS MIC JR - Mostra de Iniciação Científica Jr, O(0), 789-790.

Samanta, D. (2019). Cannabidiol: A Review of Clinical Efficacy and Safety in Epilepsy. Pediatric Neurology, 96, 24-29. https://doi.org/10.1016/j.pediatrneurol.2019.03.014

Shan, W., Chen, Y., Qiao, H., Wang, S., Wang, R., Wu, H., Wu, J., Fang, L., \& Huang, H. (2016). Ginkgo biloba extract for treating epilepsy and application of ginkgo biloba extract for treating epilepsy (Patent https://worldwide.espacenet.com/publicationDetails/biblio?FT=D\&date=20160203\&DB=EPODOC\&locale=en_EP\&CC=CN\&NR=105287657A\&KC=A\&N $\mathrm{D}=1$

Shi, M., He, W., Liu, Y., Li, X., Yang, S., \& Xu, Q. (2013). Protective effect of total phenylethanoid glycosides from Monochasma savatieri Franch on myocardial ischemia injury. Phytomedicine: International Journal of Phytotherapy and Phytopharmacology, 20(14), 1251-1255. https://doi.org/10.1016/j.phymed.2013.06.014

Shimada, T., \& Yamagata, K. (2018). Pentylenetetrazole-Induced Kindling Mouse Model. Journal of Visualized Experiments: JoVE, 136. https://doi.org/10.3791/56573

Siarava, E., Hyphantis, T., Katsanos, A. H., Pelidou, S.-H., Kyritsis, A. P., \& Markoula, S. (2019). Depression and quality of life in patients with epilepsy in Northwest Greece. Seizure, 66, 93-98. https://doi.org/10.1016/j.seizure.2019.02.012

Socała, K., Wyska, E., Szafarz, M., Nieoczym, D., \& Wlaź, P. (2019). Acute effect of cannabidiol on the activity of various novel antiepileptic drugs in the maximal electroshock- and 6 Hz-induced seizures in mice: Pharmacodynamic and pharmacokinetic studies. Neuropharmacology, 158, 107733. https://doi.org/10.1016/j.neuropharm.2019.107733

Stafstrom, C. E., \& Carmant, L. (2015). Seizures and Epilepsy: An Overview for Neuroscientists. Cold Spring Harbor Perspectives in Medicine, 5(6). https://doi.org/10.1101/cshperspect.a022426

Stott, C., Jones, N., Whalley, B., Stephens, G., \& Williams, C. (2020). 7-Oh-Cannabidiol (7-Oh-Cbd) for Use in the Treatment of Epilepsy (Patent No EP3639814 (A1)).

https://worldwide.espacenet.com/publicationDetails/biblio?FT=D\&date=20200422\&DB=EPODOC\&locale=en_EP\&CC=EP\&NR=3639814A1\&KC=A1\&N $\mathrm{D}=1$

Stott, C., Jones, N., Williams, R., \& Whalley, B. (2018). Use of Cannabinoids in the Treatment of Epilepsy (Patent No US2018228751 (A1)). https://worldwide.espacenet.com/publicationDetails/biblio?FT=D\&date=20180816\&DB=\&locale=en_EP\&CC=US\&NR=2018228751A1\&KC=A1\&ND=4

Su, C.-Y., Ming, Q.-L., Rahman, K., Han, T., \& Qin, L.-P. (2015). Salvia miltiorrhiza: Traditional medicinal uses, chemistry, and pharmacology. Chinese Journal of Natural Medicines, 13(3), 163-182. https://doi.org/10.1016/S1875-5364(15)30002-9

Sun, H., Chen, F., Wang, Q., Zhan, S., Gao, Z., \& Ren, H. (2020). Extraction method of radix stellerae chamaejasmes total alkaloids and application of radix

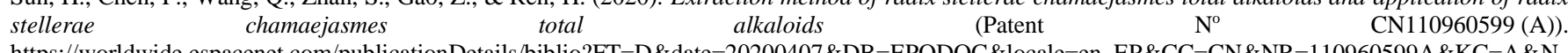
https://worldwide.espacenet.com/publicationDetails/biblio?FT=D\&date=20200407\&DB=EPODOC\&locale=en_EP\&CC=CN\&NR=110960599A\&KC=A\&N $\mathrm{D}=1$

Thijs, R. D., Surges, R., O’Brien, T. J., \& Sander, J. W. (2019). Epilepsy in adults. Lancet (London, England), 393(10172), 689-701. https://doi.org/10.1016/S0140-6736(18)32596-0 
Thurman, D. J., Beghi, E., Begley, C. E., Berg, A. T., Buchhalter, J. R., Ding, D., Hesdorffer, D. C., Hauser, W. A., Kazis, L., Kobau, R., Kroner, B., Labiner, D., Liow, K., Logroscino, G., Medina, M. T., Newton, C. R., Parko, K., Paschal, A., Preux, P.-M., ... ILAE Commission on Epidemiology. (2011). Standards for epidemiologic studies and surveillance of epilepsy. Epilepsia, 52 Suppl 7, 2-26. https://doi.org/10.1111/j.1528-1167.2011.03121.x

Tomson, T., Nashef, L., \& Ryvlin, P. (2008). Sudden unexpected death in epilepsy: Current knowledge and future directions. The Lancet. Neurology, 7(11), 1021-1031. https://doi.org/10.1016/S1474-4422(08)70202-3

Veeresham, C. (2012). Natural products derived from plants as a source of drugs. Journal of Advanced Pharmaceutical Technology \& Research, 3(4), 200201. https://doi.org/10.4103/2231-4040.104709

Verma, N., Gupta, S. K., Tiwari, S., \& Mishra, A. K. (2021). Safety of Ashwagandha Root Extract: A Randomized, Placebo-Controlled, study in Healthy Volunteers. Complementary Therapies in Medicine, 57, 102642. https://doi.org/10.1016/j.ctim.2020.102642

Vilasboas-Campos, D., Costa, M. D., Teixeira-Castro, A., Rios, R., Silva, F. G., Aierken, A., Zhang, X., Bessa, C., Dias, A. C. P., \& Maciel, P. (2020). Data on the effects of Hyptis spp. And Lycium spp. Plant extracts in C. elegans models of genetically determined neurodegenerative diseases. Data in Brief, 33, 106598. https://doi.org/10.1016/j.dib.2020.106598

Vyas, S., Kothari, S. L., \& Kachhwaha, S. (2019). Nootropic medicinal plants: Therapeutic alternatives for Alzheimer's disease. Journal of Herbal Medicine, $17-18,100291$. https://doi.org/10.1016/j.hermed.2019.100291

Wang, J., Li, Y., Huang, W.-H., Zeng, X.-C., Li, X.-H., Li, J., Zhou, J., Xiao, J., Xiao, B., Ouyang, D.-S., \& Hu, K. (2017). The Protective Effect of Aucubin from Eucommia ulmoides Against Status Epilepticus by Inducing Autophagy and Inhibiting Necroptosis. The American Journal of Chinese Medicine, 45(3), 557-573. https://doi.org/10.1142/S0192415X17500331

Wang, Y., Li, M., Liang, Y., Yang, Y., Liu, Z., Yao, K., Chen, Z., \& Zhai, S. (2017). Chinese Herbal Medicine for the Treatment of Depression: Applications, Efficacies and Mechanisms. Current Pharmaceutical Design, 23(34), 5180-5190. https://doi.org/10.2174/1381612823666170918120018

Whalley, B., Williams, C., Stephens, G., \& Futamura, T. (2018). Use of the phytocannabinoid cannabidivarin (CBDV) in the treatment of epilepsy (Patent N AU2018217303 (A1)).

https://worldwide.espacenet.com/publicationDetails/biblio?FT=D\&date=20180906\&DB=EPODOC\&locale=en_EP \&CC=AU\&NR=2018217303A1\&KC=A1 $\& \mathrm{ND}=1$

Xu, S., \& Liu, P. (2013). Tanshinone II-A: New perspectives for old remedies. Expert Opinion on Therapeutic Patents, $23(2), 149-153$. https://doi.org/10.1517/13543776.2013.743995

Yan, M., Li, M., Gu, S., Sun, Z., Ma, T., \& Ma, X. (2020). Ginkgo biloba extract protects diabetic rats against cerebral ischemia-reperfusion injury by suppressing oxidative stress and upregulating the expression of glutamate transporter 1. Molecular Medicine Reports, 21(4), 1809-1818. https://doi.org/10.3892/mmr.2020.10990

Yang, B., Liu, Y., \& Kuang, H. (2019). Antiepileptic effect of different extracts of aboveground part of bupleurum chinense (Patent $\mathrm{N}^{\circ} \mathrm{CN} 110522777$ (A)). https://worldwide.espacenet.com/publicationDetails/biblio?FT=D\&date=20191203\&DB=\&locale=en_EP\&CC=CN\&NR=110522777A\&KC=A\&ND=4

Yang, G., Wang, Y., Sun, J., Zhang, K., \& Liu, J. (2016). Ginkgo Biloba for Mild Cognitive Impairment and Alzheimer's Disease: A Systematic Review and Meta-Analysis of Randomized Controlled Trials. Current Topics in Medicinal Chemistry, 16(5), 520-528. https://doi.org/10.2174/1568026615666150813143520

Yao, I., Stein, E. S., \& Maggio, N. (2019). Cannabinoids, hippocampal excitability and efficacy for the treatment of epilepsy. Pharmacology \& Therapeutics, 202, 32-39. https://doi.org/10.1016/j.pharmthera.2019.06.002

Yu, D., Zhang, P., Li, J., Liu, T., Zhang, Y., Wang, Q., Zhang, J., Lu, X., \& Fan, X. (2020). Neuroprotective effects of Ginkgo biloba dropping pills in Parkinson's disease. Journal of Pharmaceutical Analysis. https://doi.org/10.1016/j.jpha.2020.06.002

Yu, N., Lin, X., Zhang, S., \& Di, Q. (2019). Analysis of the reasons and costs of hospitalization for epilepsy patients in East China. Seizure, 72, 40-45. https://doi.org/10.1016/j.seizure.2019.09.013 